\title{
Managing Debris Flow Risks
}

Author(s): Markus Zimmermann

Source: Mountain Research and Development, 24(1):19-23.

Published By: International Mountain Society

DOI: http://dx.doi.org/10.1659/0276-4741(2004)024[0019:MDFR]2.0.CO;2

URL: http://www.bioone.org/doi/full/10.1659/0276-4741\%282004\%29024\%5B0019\%3AMDFR

$\% 5 \mathrm{D} 2.0 . \mathrm{CO} \% 3 \mathrm{~B} 2$

BioOne (www.bioone.org) is a nonprofit, online aggregation of core research in the biological, ecological, and environmental sciences. BioOne provides a sustainable online platform for over 170 journals and books published by nonprofit societies, associations, museums, institutions, and presses.

Your use of this PDF, the BioOne Web site, and all posted and associated content indicates your acceptance of BioOne's Terms of Use, available at www.bioone.org/page/terms_of_use.

Usage of BioOne content is strictly limited to personal, educational, and non-commercial use. Commercial inquiries or rights and permissions requests should be directed to the individual publisher as copyright holder.

BioOne sees sustainable scholarly publishing as an inherently collaborative enterprise connecting authors, nonprofit publishers, academic institutions, research libraries, and research funders in the common goal of maximizing access to critical research. 


\title{
Managing Debris Flow Risks
}

\author{
Security Measures for a Hazard-Prone Resort in Switzerland
}

Debris flows represent a widespread threat to villages and small towns in the Swiss Alps. For many centuries people "managed" such risks by trying to avoid hazardous areas. However, major debris flow and flood events in the last 25 years have revealed that the degree of freedom to engage in this type of risk management has substantially decreased. This became especially evident during the 1999 disasters in a number of places in Switzerland. The winter of that year was unusually wet. In February heavy snowfall triggered destructive avalanches. In May high temperatures caused heavy snowmelt, with excessive rainfall contributing more water to the already saturated soils. Landslides, debris flows and floods were triggered in many locations, including Sörenberg. Hazard prevention and disaster management have a long tradition in Switzerland, although an integrated approach to risk management is rather new. Only in recent years have methods and tools been developed to assess hazards, define protection goals, and implement disaster reduction measures. The case of Sörenberg serves as an example of how today's approaches to disaster reduction are implemented at the local level.

\section{The events of 1999}

Sörenberg is a typical small tourist resort located on the periphery of the Swiss Alps in Central Switzerland (Figure 1). The village has developed only during the last 40 years; prior to that, it was known as a spa. Today, about 800 housing units-mainly secondary homes (chalets and tourist apartments) - are situated on old debris flow deposits. In addition, a number of sports and leisure facilities have been constructed in recent years. The slopes above the village belong to a large ( 15 million $\mathrm{m}^{3}$ ) and deep-seated (100 m) landslide complex (sagging or rock flow). Signs of instability in this area have been apparent since the mid $19^{\text {th }}$ century or even earlier.

On 14 May 1999 this landslide complex showed increased activity, as was the case in many other landslide areas of Switzerland. Approximately 250,000 $\mathrm{m}^{3}$ of rock detached from the main mass. This collapse is presumed to have been triggered by the accumulation of snowmelt from March to May, as well as by $30 \mathrm{~mm}$ of rainfall on 14 May. Debris

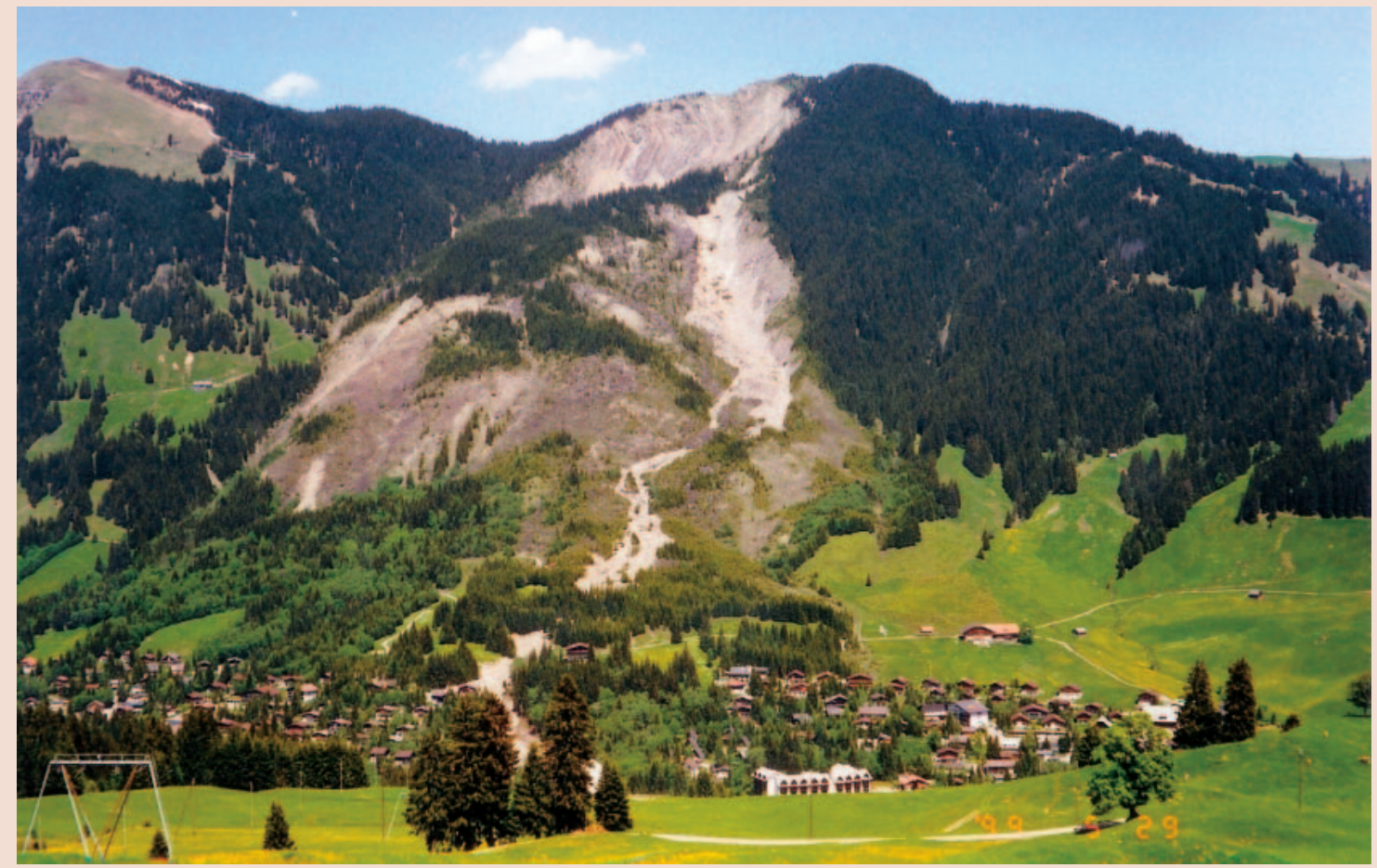

FIGURE 1 The tourist resort of Sörenberg, located in the Entlebuch Biosphere Reserve, Central Switzerland. The village is located at the foot of a deep-seated landslide complex. The bright surfaces mark the geomorphological zones active in 1999. (Photo by author) 


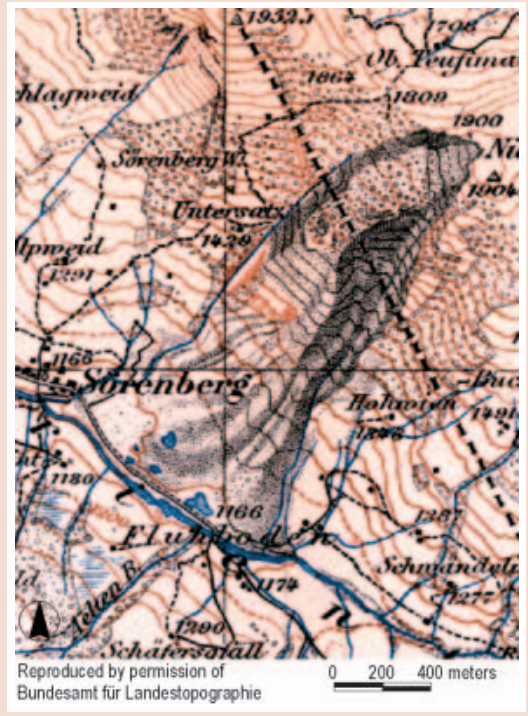

FIGURE 21918 topographic map, showing the open scars on either side of the mass and the typical accumulation features developed in 1910 and 1912. The few houses with the church (at the center of the village) are located in a safe place. (Map reproduced by permission of Bundesamt für Landestopographie, BA024084) flows, originating in the freshly deposited soils, developed and traveled downhill for days, weeks and months following 14 May. All flows followed the course of a small creek and arrived in an open space between 2 village districts $150 \mathrm{~m}$ in width (housing lots not yet occupied). Surprisingly, no avulsion occurred on the debris flow fan. Hence damage in the densely populated village districts was rather limited.

\section{Management of recent disasters}

These events took the municipal authorities completely by surprise. They immediately established a number of emergency measures to protect inhabitants, prepare for further debris flows, and generally manage the crisis, including:

- Establishment of a crisis management committee with a crisis management center for overall coordination;

- Formulation of evacuation plans for approximately 100 houses. Special consideration had to be given to frequent tourist turnover in the chalets;

- Visual monitoring of the zone where the debris flow originated: volunteers (mainly elderly persons living in the village) were asked to observe conditions in the headwaters;

- Installation of wire sensors in two locations to detect debris flows;

- Regular geodetic survey of the large moving rock mass (every 2 to 3 months);

- Installation of a continuously recording rain gauge in the headwaters;

- Implementation of small-scale structural measures such as dams, channel excavation, etc.

Due to ongoing debris flow activitynearly every minor rainfall event was followed by a debris flow-the above-mentioned measures remained effective throughout the year. After initial assessment of the situation, it was decided to perform an in-depth analysis of the conditions, establish a hazard map, and propose long-term solutions for the protection of the village and its inhabitants.

\section{Past events: a key to current risks?}

Analysis of past events makes an important contribution to the understanding of present and future hazards in a particular location. A number of historic documents such as maps (Figure 2), postcards or photographs, as well as a detailed description of the 1910 events by the famous geologist Albert Heim, provided the necessary information to reconstruct the sequence of landslide events in the $20^{\text {th }}$ century. Between 1860 and 1910 the entire complex shifted downhill by more than $30 \mathrm{~m}$ in a large vertical movement. In 1910 another large vertical movement occurred, lasting several days and causing 2 major lateral collapses and massive debris flows of over 3 million $\mathrm{m}^{3}$. Throughout the rest of the $20^{\text {th }}$ century development was irregular. Several lateral and frontal collapses occurred in 1912 , 1922, and 1986, with 6 decades of geomorphic inactivity in between.

At the beginning of the $20^{\text {th }}$ century the area now occupied by the village was used as grazing land. The map (Figure 2) indicates that the existing few houses in Sörenberg were arranged around the church in a safe place. Within the accumulation area of the 1910, 1912 and 1922 debris flows, only a very few isolated houses were destroyed.

Sörenberg's development into the tourist resort that it is today took place only over the past 30 to 40 years. The 1918 map (Figure 2) clearly shows that at that time only very few buildings were located in what was once a highly active accumulation area. Today this area is completely covered by houses (Figure 3 ). The long period of geomorphic inactivity following the events of 1922 was interpreted as a sign of future security. An analysis by experts in 1974 proved that there was no immediate threat, but did not altogether exclude the possibility of damaging events. An indication of the uncertainty of the situation was provided by displacement measurements begun in 1978. These clearly show that the whole mass is continuously moving about 3 to $10 \mathrm{~cm}$ per year. The speed of this movement increased dramatically in 1999 but has slowed down again since. 
Secondary processes caused by primary movement occur only after relatively long intervals. It can be concluded that Sörenberg remains at risk. The risk of further collapses and subsequent flows must be taken into account, even though conditions above the village are currently calm. However, it is assumed that large-scale events such as the ones in 1910 are no longer possible. These facts were considered in the hazard map that was prepared in 2001 (Figure 4A).

\section{Long-term solutions at the village level}

The first step towards definition of protective measures is a thorough investigation of all hazards and the creation of a hazard map. In Switzerland, such maps are based on definite probability and magnitude classes. Under present conditions, most of the village is within red and blue hazard zones (Figure 4A), ie those subject to a high or moderate risk, respectively. This constitutes a de facto ban on future economic development of the village: construction of new houses and major changes to existing houses are normally not permitted within the red zone. This, of course, was not acceptable to the municipal authorities. Solutions had to be found that would guarantee the safety of the population while at the same time allowing moderate development of the village.

According to the municipal authorities, structural protection measures need to be implemented in order to "reduce the colors" on the hazard map. Cantonal authorities, on the other hand, call for an integrated approach to risk and disaster reduction. To them it is obvious that the principal hazards cannot be completely eliminated. In the case of Sörenberg the following protection goals were defined for events at different intervals:

- Once every 30 years: damage not acceptable;

- Once a century: limited degree of damage acceptable;

- Once every 300 years: limited protection for assets provided;

- Casualties are not acceptable for any type of event.
A number of structural and non-structural measures were planned between 2001 and 2003 with these protection goals in mind. They are currently being discussed among local, cantonal and federal authorities. The local population has been informed through public hearings and publication of the various projects. Residents have the right to make objections. The measures include:

\section{Land use planning:}

- A set of regulations in the local land use plan and building code defines what is possible in red, blue and yellow zones. These regulations should curb further increase of vulnerability (see Table 1 and Figure 4B).

- In addition to village regulations, plans call for a complete ban on grazing throughout the landslide-prone area as well as an increase in forest cover.

- Municipal and cantonal authorities established a hazard map for the whole area in order to show whether adjacent areas are more suitable for village development. Unfortunately, there are only a few places that are appropriate as housing lots.

\section{Structural measures:}

- People argued that the primary process should be stopped. Geophysical investigations showed, however, that control of the water table in this extremely fractured and fast-moving mass is hardly possible;

- A number of (reasonable) structural protection measures (Figure 4B, green markings) are planned to reduce the risks to a bearable level. But even with these protection measures, some parts of the village remain in the red danger zone. Owing to financial constraints, the state would like to minimize these measures. The local authorities, on the other hand, have an interest in reducing the red zone as much as possible. Costs of about CHF 14 million (US $\$ 10$ million) will be shared by the canton and the municipality, with heavy subsidies from the federal government. Home owners may also make contributions.

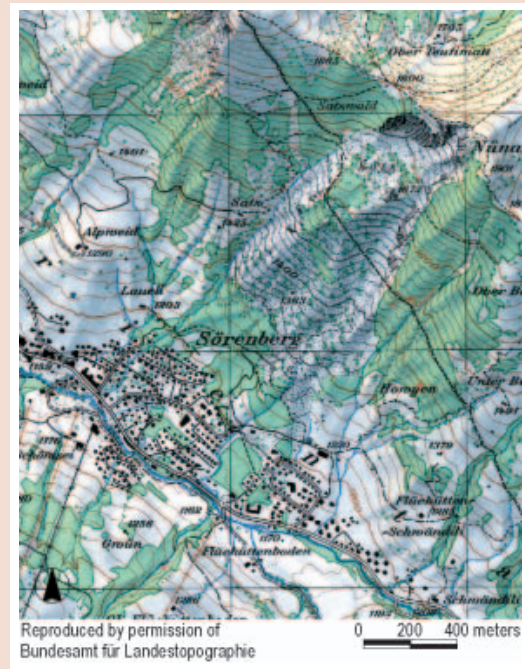

FIGURE 31993 topographic map, showing how the village has developed in the past 30 years in the area where debris flow formerly accumulated. (Map reproduced by permission of Bundesamt für Landestopographie, BA024084) 
FIGURE 4, A AND B Hazard map for Sörenberg. Top (A) before, and bottom (B) after the implementation of the planned structural measures. Red: high degree of hazard; blue: moderate degree of hazard; yellow: low degree of hazard; yellowwhite: hazards with a very low probability of occurrence; green: planned structural measures. (Maps reproduced by permission of swisstopo, BA035840)
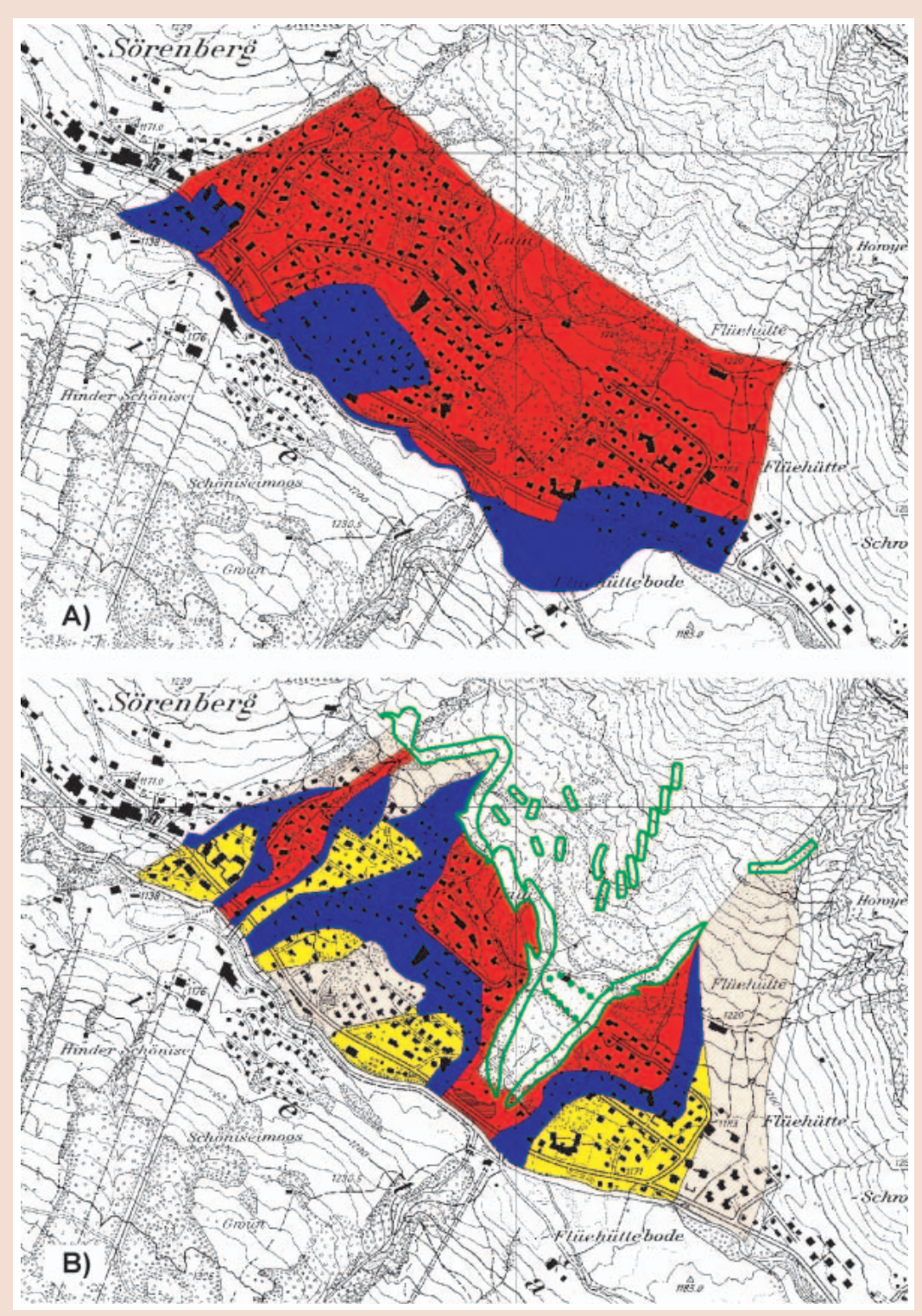

Emergency planning: Public safety cannot be fully guaranteed by structural measures. Emergency measures should provide additional risk reduction:

- Long-term monitoring: regular displacement measurements (every half year) and continuous rainfall (threshold values for rainfall exist) are used for early warning;

- Short-term observation: visual observation in case of increased instability (as successfully implemented in 1999); wire sensors to detect ongoing debris flow activity and instantaneous rainfall intensity provide information to alarm and evacuate people.

This set of measures should guarantee the safety of the population and existing assets. It also should guarantee further development of the village in areas where this is suitable.

\section{Concerns and constraints}

Design of structural measures was accomplished in autumn 2003 and the public had a chance to react to the project. Land use plans and the building code now need to be approved in a referendum (2004). Current expert opinion clearly differs from public opinion, at least among part of the population. The reasons are manifold:

- There are still major uncertainties about natural processes, even after detailed investigations. A new event (similar to that of 1999 or even bigger) could occur within the next year. On the other hand, the next 20 or 30 years could also remain calm. It is important to communicate these uncertainties to local authorities and residents. Moreover, such uncertainties increase when environmental change is considered.

- People have a hard time understanding probabilities of $0.03,0.01$ or even less. For most people, the next 10 to 20 years are a relevant time frame. An event that occurs statistically once in 100 years is something very abstract.

- The movements of the entire mass have slowed in the last 2 years. In the popular mind, this is a sign of improvement.

- Public safety is guaranteed by a set of measures. Whereas land use regulations and structural measures have a permanent effect, preparedness measures require awareness over years or even decades. It is doubtful that such awareness can be maintained for infrequent events.

- Enforcement of land use regulations (particularly in the red zone) will become increasingly difficult if no events, even small-scale debris flows, occur in the coming years. 
TABLE 1 Overview of hazard zones and building restrictions in Sörenberg.

\begin{tabular}{|c|c|c|}
\hline Degree of risk & New buildings & Existing buildings \\
\hline High & Construction of new buildings prohibited & $\begin{array}{l}\text { Normal maintenance of buildings permit- } \\
\text { ted. Modifications only if number of per- } \\
\text { sons in a building is not increased }\end{array}$ \\
\hline Moderate & $\begin{array}{l}\text { No planning of new residential areas. } \\
\text { Construction on existing housing lots per- } \\
\text { mitted under local protection }\end{array}$ & $\begin{array}{l}\text { Modification only with increased safety } \\
\text { measures (local protection): eg, elevated } \\
\text { entrance, no dormitories in basement, etc }\end{array}$ \\
\hline Low & $\begin{array}{l}\text { Local protection recommended; required } \\
\text { for sensitive buildings }\end{array}$ & No restrictions \\
\hline Very low & Not considered & Not considered \\
\hline
\end{tabular}

\section{Conclusions}

Centuries ago people tried to manage natural risks by avoiding endangered zones. Nowadays this strategy is no longer possible. Most of the safe places are taken. Other measures are required to reduce the prevailing risks and enable further development. The Swiss strategy takes an integrated approach in which structural and non-structural measures are balanced and together contribute to public safety and protection of assets. Preferences vary, depending on point of view (home owners and municipal, cantonal or federal authorities).
Structural measures in Sörenberg will protect existing assets to a certain degree and enable further development. However, parts of the village will have relatively strict restrictions prohibiting the construction of new buildings. Wellfunctioning preparedness measures also contribute to safety. This requires a certain level of awareness over years or decades. If the mountain continues to move and small debris flows occur occasionally, it will be easier to maintain this awareness and to enforce land use regulations.

\section{ACKNOWLEDGMENTS}

The author is indebted to Markus Liniger (Geotest), Karl Grunder (Oeko-Be), and Gabi Hunziker (Geo7) for fruitful discussions during work carried out at Sörenberg. Rene Graf, Bruno Schmid, Walter Baumann, Theo Schnider and other local authorities (canton, municipality) were very appreciative customers and interested discussion partners. Ursina Holliger contributed highly valuable information from her thesis.

\section{AUTHOR}

Markus Zimmermann

Riedstrasse 5, 3600 Thun, Switzerland.mn.z@gmx.ch Markus Zimmermann is a geomorphologist specializing on natural disaster reduction, with experience in Switzerland and overseas. He works as a consultant for the Swiss Agency for Development and Cooperation (SDC), United Nations agencies, and other organizations.

\section{FURTHER READING}

FOWG [Swiss Federal Office for Water and Geology], SDC [Swiss Agency for Development and Cooperation]. 2001. Flood Protection in Switzerland: Strategy 2001. Berne, Switzerland: FOWG and SDC. See also the following document: www.bwg.admin.ch/themen/natur/e/pdf/ wlhwsfg.pdf

Dikau R, Brunsden D, Schrott L, Ibsen M-L, editors. 1996. Landslide Recognition. Chichester: Wiley. Hegg C, Badoux A, Graf C, Röthlisberger G. 2000. Unwetterschäden in der Schweiz im Jahre 1999. wasser energie luft 92 (3/4):59-68.

Heim A. 1932. Bergsturz und Menschenleben. Zurich, Switzerland: Fretz und Wasmuth.

Zimmermann M, Mani P, Romang H. 1997. Magnitudefrequency aspects of Alpine debris flows. Eclogae geologicae Helvetiae 90:415-420. 